\title{
Integrated stratigraphy across the Paleocene/Eocene boundary in the Contessa Road section, Gubbio (central Italy)
}

\author{
by SimONe GALEOTTI ${ }^{1}$, EUGENIA ANGORI ${ }^{2}$, RODOLFO COCCIONI ${ }^{1}$, GABRIELla FERRARI ${ }^{3}$, BRUNO GALBRUN ${ }^{4}$, \\ SIMONETTA MONECHI ${ }^{2}$, ISABELLA PREMOLI SILVA ${ }^{3}$, ROBERT SPEIJER ${ }^{5}$ and BRUNO TURI ${ }^{6}$
}

Key words. - Paleocene-Eocene transition, Integrated stratigraphy, Contessa road section.

Abstract. - An integrated stratigraphic study of the upper Paleocene to lower Eocene Scaglia limestones of the Contessa Road section has allowed us to identify the classical markers of the Paleocene-Eocene transition. The section provides a good magnetostratigraphic record as well as a continuous ( calibration to calcareous plankton zonation indicates that the CIE occurs in the lowermost part of calcareous nannofossil Zone NP10 and the upper part of Zone CP8, that is in the planktonic foraminiferal Zone P5. In the same stratigraphic interval, a distinct turnover in the calcareous benthic foraminifera and a sharp change in the Deep Water Agglutinated Foraminiferal (DWAF) assemblages have been recognised. The record of DWAF, however, indicates a gradual initiation of such a change beginning some $150 \mathrm{k} . \mathrm{y}$. before the CIE and BEE.

\section{Stratigraphie intégrée de part et d'autre de la limite Paléocène/Eocène de la coupe de la route de la Contessa, Gubbio (Italie centrale)}

Mots clés. - Transition Paléocène-Eocène, Stratigraphie intégrée, Coupe de la « Contessa Road ».

Résumé. - Nous apportons une contribution à une meilleure définition de la position relative des différents événements de la transition P/E à travers une étude stratigraphique intégrée de la coupe de la Comtessa dans le bassin de Marche-Ombrie. Des analyses magnéto- chémio- et biostratigraphiques ont été menées incluant la distribution des nannofossiles calcaires et des foraminifères ainsi que des données sur les isotopes du carbone et de l'oxygène.

\section{VERSION FRANÇAISE ABRÉGÉE}

Résumé. - Une étude stratigraphique intégrée des calcaires du Paléocène supérieur-Eocène inférieur de la coupe de la "Contessa» nous a permis d'identifier les marqueurs typiques de la transition Paléocène-Eocène. La coupe fournit un bon enregistremement magnétostratigraphique ainsi qu'une biostratigraphie continue à nannofossiles calcaires et foraminifères. Une excursion négative des isotopes du carbone (CIE) s'observe dans la partie inférieure du Chron C24r. L'étalonnage avec la zonation à plancton calcaire indique que la CIE se situe dans la partie la plus inférieure de la Zone à nannofossiles calcaires NP10 (= partie supérieure de la Zone CP8), et dans la Zone à foraminifères planctonique P5. Dans le même intervalle stratigraphique, ont été identifiés un renouvellement taxonomique distinct dans les associations à foraminifères benthiques calcaires et un changement important dans les associations à foraminifères agglutinés (DWAF). Cependant, l'enregistrement de DWAF indique un commencement graduel du dit changement à partir de 150 ka avant le CIE et le BEE.

\section{INTRODUCTION}

During the late Paleocene to early Eocene significant changes in global climate and oceanic circulation occurred. Such changes resulted in evolutionary turnovers and extinctions which are recorded in both marine and terrestrial environments. Long timescale events occurred over several millions of years (m.y.) in paleomagnetic Chrons C25 and C24. Superimposed on a longer-term warming trend which began in the early Paleocene, short term changes in climate and carbon cycle occurred at the Paleocene-Eocene (P-E) transition where a large, negative excursion in the carbon isotope record [Kennett and Stott, 1991; Stott et al., 1996; Thomas and Shackleton, 1996] is associated with a major extinction event in the deep sea [Thomas, 1989; Kennett and Stott, 1991; Kaiho, 1994; Robert and Kennett, 1994]. Although the co-occurrence of these two events provides a reliable means of determining the position of the $\mathrm{P} / \mathrm{E}$ boundary in marine sequences, their position in space and time still does not have an unequivocal significance.

This paper aims to contribute to a better definition of the relative position of the different events within the P-E transition through an integrated stratigraphic study of the Contessa Road section in the Umbria-Marche Basin. A megneto-, bio-, and chemo-stratigraphic analysis has been carried out including foraminiferal and calcareous nannofossil distribution, and carbon and oxygen isotope record.

\section{GEOLOGIC AND STRATIGRAPHIC FRAMEWORK}

In the Umbria-Marche Basin the P-E transition is represented in the pelagic reddish limestones of the Scaglia Rossa Formation which is suitable for precisely correlating the

${ }^{1}$ Istituto di Geologia and Centro di Palinologia dell'Università, Località Crocicchia, 61029 Urbino, Italy.

2 Dipartimento di Scienze della Terra, Via La Pira 4, 50121 Firenze, Italy.

3 Dipartimento di Scienze della Terra, Via Mangiagalli 34, 20133 Milano, Italy.

4 ESA-CNRS 7073 1761 Département de Géologie Sédimentaire, Université Pierre-et-Marie-Curie, 4, place Jussieu, 75252 Paris, France.

5 Department of Geosciences, Bremen University, P.O. Box 330440, 28334 Bremen, Germany.

6 Dipartimento di Scienze della Terra, Università di Roma La Sapienza, P.le Aldo Moro 5, 00185 Roma, Italy. 


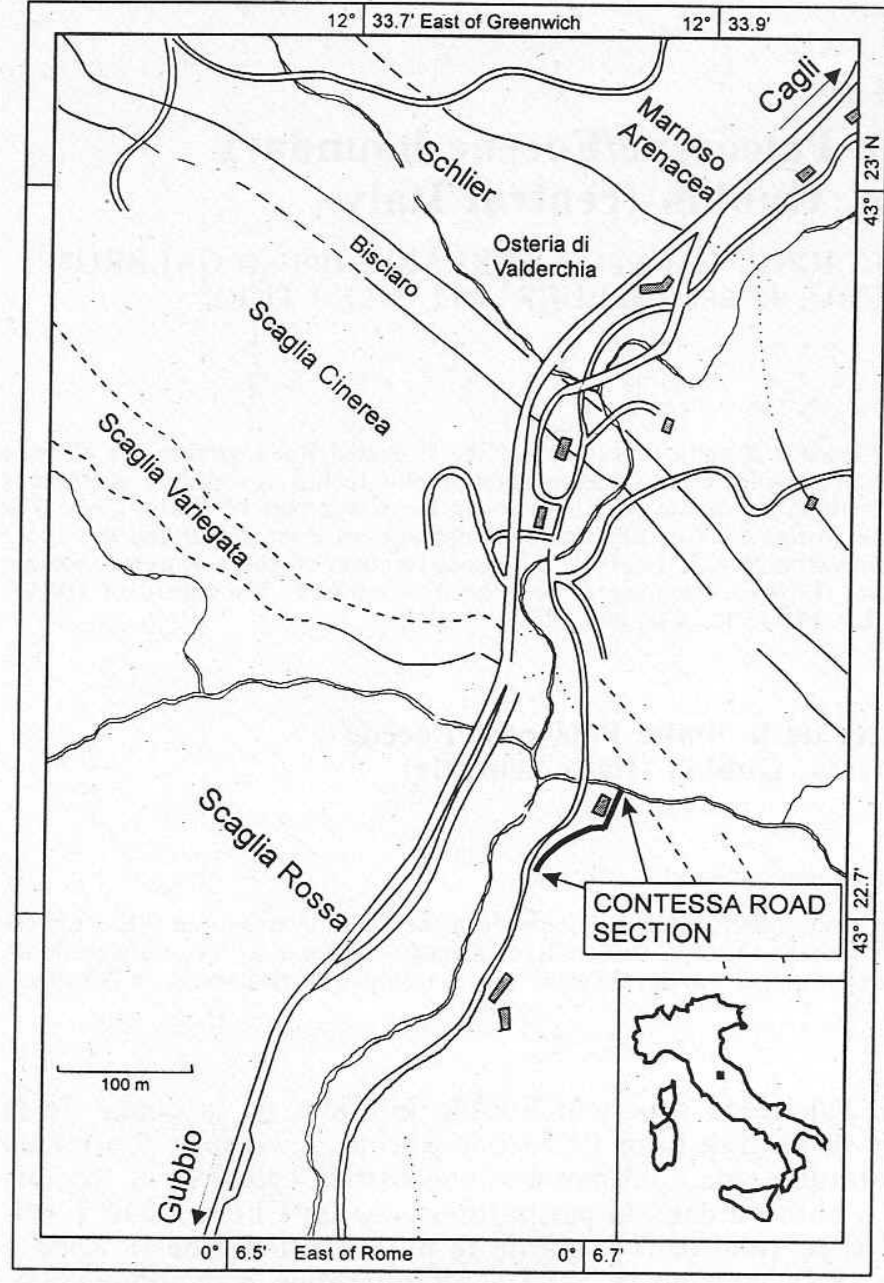

FIG. 1. - Location of the Contessa Road section marked with a thick line on a simplified map that gives the formation boundaries in the Contessa Valley [after Cresta et al., 1989, modified].

FIG. 1. - Emplacement de la coupe de la "Contessa Road» marqué par une ligne épaisse sur une carte simplifiée offrant les limites de formation dans la Vallée Contessa [d'après Cresta et al., 1989, modifié].

Paleogene biostratigraphy to the geomagnetic polarity history. In particular, magnetostratigraphic, lithostratigraphic and biostratigraphic investigations in the Gubbio sections provide geomagnetic reversal stratigraphy for most of the Paleogene interval [Lowrie et al., 1982; Napoleone et al., 1983], while geochemical analysis from the Contessa Highway section records a carbon isotope record including a negative shift of $\delta^{13} \mathrm{C}$ at the P-E transition [Corfield et al., 1991]. However, minor tectonic disturbance and/or the presence of covered intervals have hampered a detailed study of the P-E transition in this classical Tethyan setting. In the Contessa Highway section a $1 \mathrm{~m}$-thick covered interval prevents a continuous sampling of the P-E transition which is, in turn, associated with a slump in the Bottaccione section [Cresta et al., 1989]. To overcome these problems the Contessa Road section (fig. 1), previously studied by Luterbacher [1964], has been sampled in detail across the P-E transition.

The Contessa Road section begins at the Cretaceous/Paleogene (K/P) boundary and continues up to the varicoloured marls and limestones of the Eocene Scaglia Variegata Formation. The P-E transition is represented by a sequence of limestones and marly limestones with some marly layers ranging from 0.5 to $10 \mathrm{~cm}$ in thickness. At $30.30 \mathrm{~m}$ a distinct, $10 \mathrm{~cm}$-thick clayey layer interrupts the sequence of limestones and marls.

The magnetostratigraphy of the Contessa Road section has been carried out by Lowrie et al. [1982]. The sedimentation rate of the $17 \mathrm{~m}$-thick sequence corresponding to Chron C24r [Lowrie et al., 1982] is estimated to be around $7 \mathrm{~m} / \mathrm{m} . \mathrm{y}$., according to Berggren et al.'s [1995] time scale.

The present study focuses on a 10 m-thick segment (23.50 $\mathrm{m}$ to $33.50 \mathrm{~m}$ above the $\mathrm{K} / \mathrm{P}$ boundary) that includes the P-E transition and, according to Lowrie et al. [1982], would span the upper part of Chron C25n and the lower part of C24r (see fig. 2). Although a $1.7 \mathrm{~m}$-thick duplicated interval is present within Chron C25n (fig. 2), the section provides an apparently continuous record across the $\mathrm{P} / \mathrm{E}$ boundary and is characterised by:

- a pelagic sedimentation which minimises the risk of reworking;

- high calcareous plankton content which allows a calibration to standard nannofossil and planktonic foraminiferal zonations ;

- a very good magnetostratigraphic record; according to magnetostratigraphic data of Lowrie et al. [1982], the Contessa Road section seems to provide the best record across the P-E transition in the Gubbio area.

Moreover, the presence of both calcareous and Deep Water Agglutinated Foraminifera (DWAF) permits to directly calibrate their records across the Benthic Extinction Event (BEE).

We believe that, although condensed, the Contessa Road can serve as a good reference section for the P-E transition.

\section{MATERIAL AND METHODS}

The objective of the magnetostratigraphic study was to establish precisely the position of Chron C25n which occurs a few meter below the P-E transition as previously established by Lowrie et al. [1982]. Paleomagnetic samples were cored using a portable gasoline drill; 29 regularly spaced minicores were collected on the studied interval from 19.50 to $37.50 \mathrm{~m}$ above the K/P boundary.

The magnetic properties of the Scaglia limestones are well known [Channell et al., 1982; Lowrie et al., 1982]. The magnetite, assumed to be detrital in origin, is present in all lithologies. Its high contribution to the remanence allows to easily identify the stable primary characteristic remnant magnetisation (ChRM) components after thermal demagnetisation. Our samples were measured with a 3 -axis, RS-01 (LETI/CEA) cryogenic magnetometer in the Département de Géologie sédimentaire, Université Paris VI. All the specimens were subjected to progressive thermal demagnetisation in 50-degree steps up to $450{ }^{\circ} \mathrm{C}$ and in $25^{\circ}$ steps up to $550^{\circ} \mathrm{C}$. Vector diagrams were used to identify the remnant magnetisation components and the direction of the ChRM was determined by a routine Principal Component Analysis technique on each sample.

Carbon and oxygen isotope analysis were conducted on bulk rock. Twenty-two samples from $26.50 \mathrm{~m}$ to $34.50 \mathrm{~m}$ have been analysed at the Centro di Studio per il Quaternario e l'Evoluzione dell'Ambiente of the La Sapienza University of Rome following the conventional procedure of Mc Crea [1950]. The $\mathrm{CO}_{2}$ from calcite was extracted by reaction of powered samples with ortophosphoric acid $\left(\mathrm{H}_{3} \mathrm{PO}_{4} 100 \%\right)$ at $25^{\circ} \mathrm{C}$ using a vacuum extraction line. The relative abundances of the ${ }^{13} \mathrm{C}$ and ${ }^{18} \mathrm{O}$ isotopes were de- 


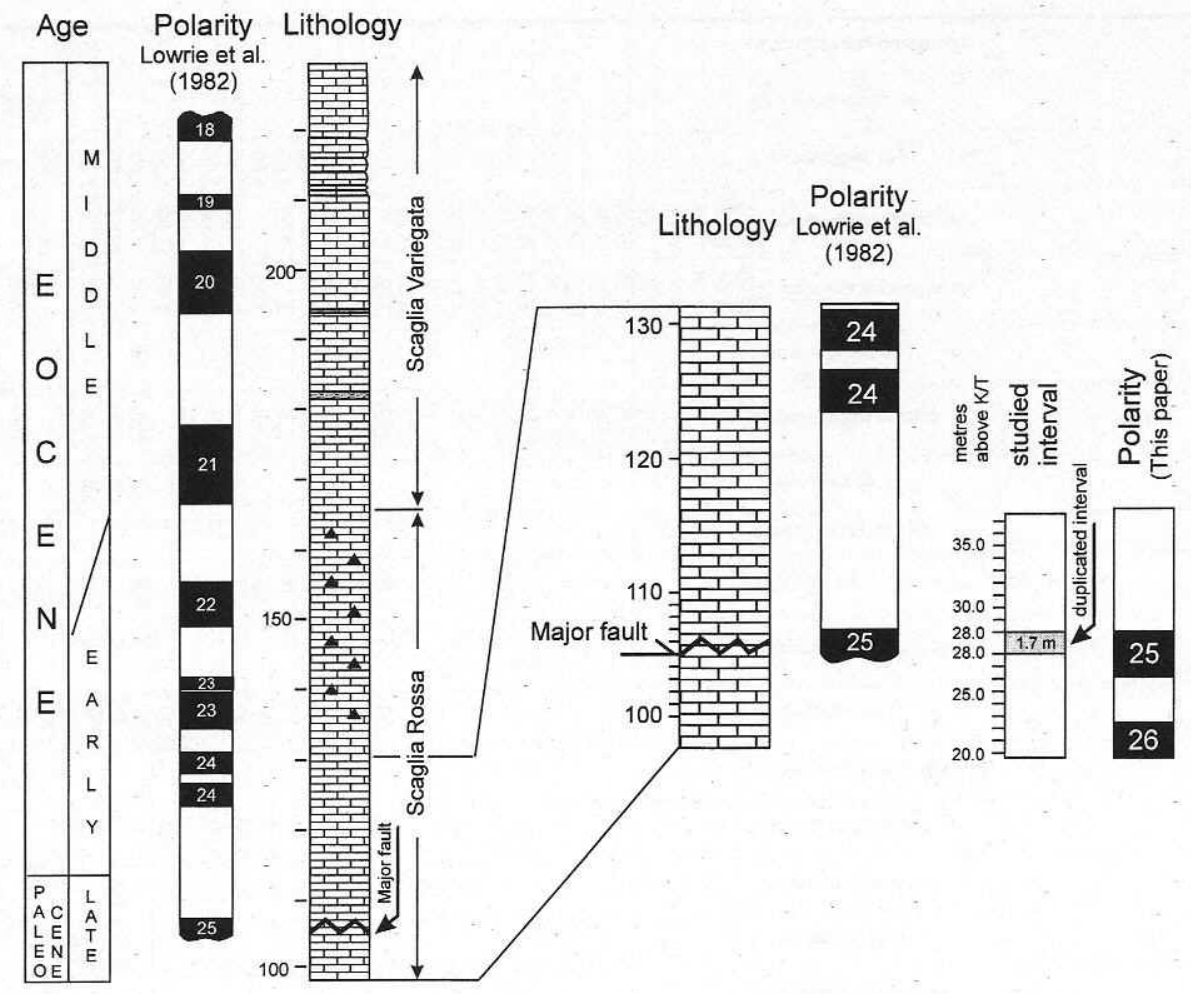

FIG. 2. - Stratigraphic position of the studied interval with respect to lithology and magnetostratigraphy of the Contessa Road section. The shaded area in the column representing the studied interval indicates the $1.7 \mathrm{~m}$-thick duplicated interval (see also the text).

FIG. 2. - Position stratigraphique de l'intervalle étudié par rapport à la lithologie et à la magnétostratigraphie de la coupe de la « Contessa Road ». La zone grisée dans la colonne représentant l'intervalle étudié, indique un intervalle dupliqué de 1,7 m d'épaisseur (voir également le texte).

termined with a d-E Finnigan Mat Mass Spectrometer. Results are reported in the usual $\delta$-notation relative to PDB.

Thirty-one samples were collected for planktonic foraminiferal and calcareous nannofossil content. A supplementary sample set including 11 samples from $33.50 \mathrm{~m}$ to 38.81 $\mathrm{m}$ above the K/P boundary has been surveyed for nannofossil content.

Calcareous nannofossil analysis has been performed by light microscopy at $1250 \mathrm{X}$ magnification. Smear-slides were prepared following the Monechi and Thierstein [1985] technique without decanting the suspension. Qualitative and semiquantitative methods have been used. Semiquantitative analyses were performed by counting the index species relative to the total nannofossil assemblage (about 150 specimens); moreover, Discoaster individuals have been counted on a fixed area ( 70 fields). Abundance of selected species is reported as the number of specimens/150 nannofossils on table I.

Planktonic foraminifera were studied in washed residues and thin sections from soft and hard lithologies, respectively. Preparation of washed residues included drying overnight at $60^{\circ} \mathrm{C}$, soaking in a peroxide solution and sieving through a $63 \mu \mathrm{m}$-mesh sieve. Only qualitative data from both washed residues and thin sections are reported in this paper, whereas a paper on planktonic foraminiferal quantitative data is in progress.

Stratigraphic ranges of calcareous benthic foraminifera were determined on 8 less indurated samples. Washed residues were obtained by drying $25-130 \mathrm{~g}$ of material at $60^{\circ} \mathrm{C}$ and soaking in deionized water. This procedure was repeated several times until the material was partly disaggregated. The $<2 \mathrm{~mm}$ fraction was dried and immersed for one day in the concentrated soap "Rewoquat". After washing this procedure yielded, depending on the carbonate content of the rock, relatively clean residues. The fraction $>125 \mu \mathrm{m}$ was investigated for stratigraphic distribution patterns.

A quantitative analysis on Deep Water Agglutinated Foraminifera (DWAF) has been carried out on acid treated residues. Samples were dried, weight and soaked in a hydrochloric acid solution (5\%). After removal of the carbonate fraction, samples were washed on a $63 \mu \mathrm{m}$-mesh sieve and dried. A suitable split with approximately 200-400 specimens was obtained from the fraction greater than 63 $\mu \mathrm{m}$ with a microsplitter. From this split all the specimens were picked, counted and mounted on micropaleontological slides.

\section{RESULTS}

\section{Magnetostratigraphy}

The natural remnant magnetisation (NRM) intensities of the analysed samples range from $10^{-4}$ to $1.3 \times 10^{-3} \mathrm{~A} / \mathrm{m}$. Thermal demagnetisation was effective to isolate three distinguishable magnetic components. This behaviour is exactly similar to the one described previously [Channell et al., 1982; Lowrie et al., 1982].

An initial unstable component was removed by $150{ }^{\circ} \mathrm{C}$ heating and has the present Earth's field direction: it is most likely a viscous remnant magnetisation. A second component is removed over the range $150-300 / 350{ }^{\circ} \mathrm{C}$ and is antiparallel to the present field direction. The origin of this secondary component was not clearly established [Channell 


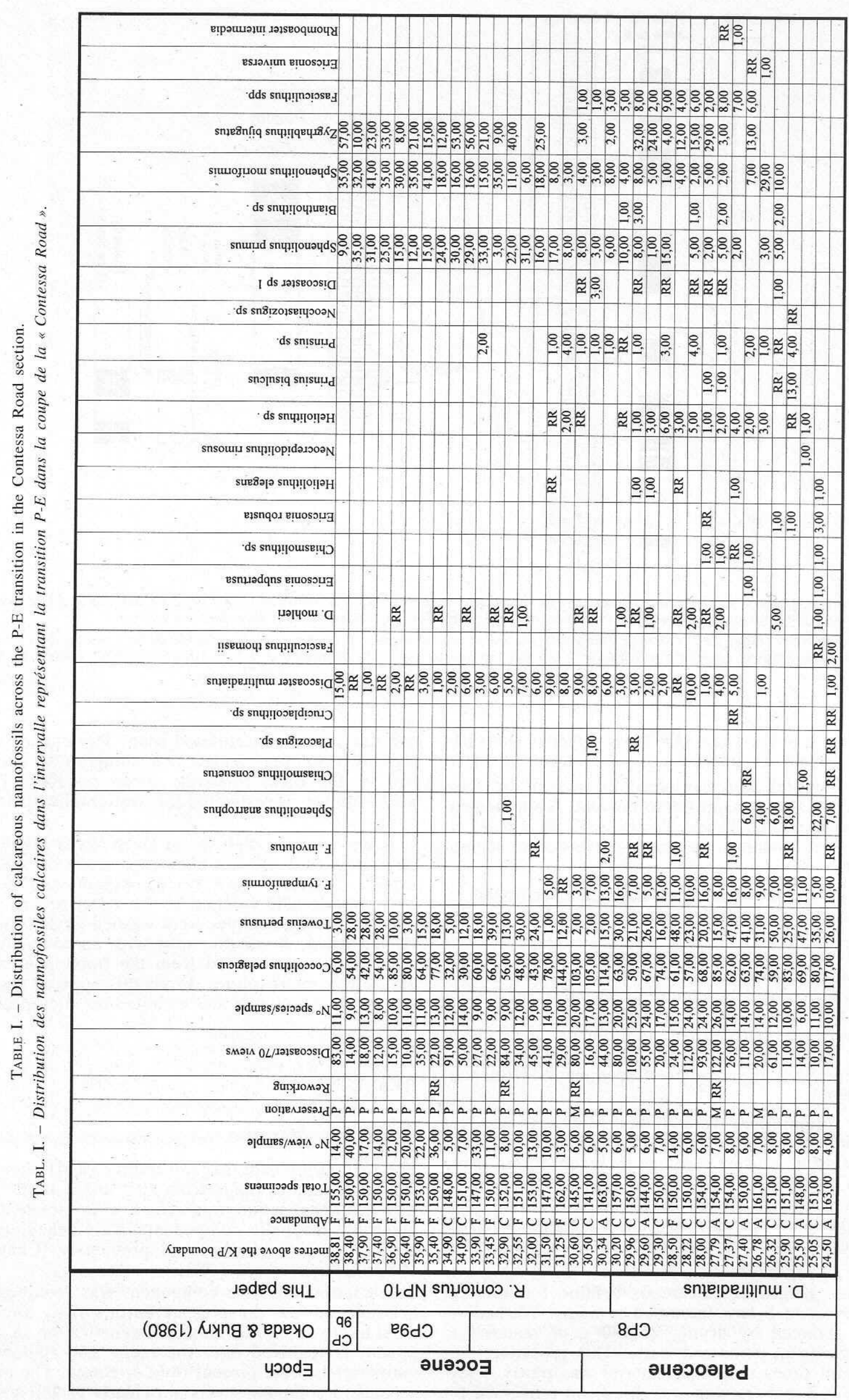







et al., 1982]. Above $300 / 350{ }^{\circ} \mathrm{C}$ the $\mathrm{ChRM}$ component is isolated. The mean direction obtained from the best defined ChRM components $(\mathrm{D}=328.4, \mathrm{I}=34.8)$ is close to the paleodirection computed by Lowrie et al. [1982].

The ChRM directions show a clear pattern of magnetozones which can be easily identified with the aim of biostratigraphic data. The $\mathrm{C} 26 \mathrm{n} / \mathrm{C} 25 \mathrm{r}$ boundary is defined between $22.3 \mathrm{~m}$ and $23.4 \mathrm{~m}$ above the $\mathrm{K} / \mathrm{P}$ boundary; the base of magnetozone $\mathrm{C} 25 \mathrm{n}$ occurs between $26 \mathrm{~m}$ and 26.4 $\mathrm{m}$ and the top between $28 \mathrm{~m}$ and $28.5 \mathrm{~m}$ (see fig. 2).

\section{Isotope record}

$\delta^{13} \mathrm{C}$ values recorded from $26.50 \mathrm{~m}$ to $34.50 \mathrm{~m}$ range from $0.31 \%$ to $3.12 \%$ (fig. 3 ). The lowest value is recorded from a clayey layer at $30.30 \mathrm{~m}$. This negative peak is preceded by a gradual decrease from the maximum value which is recorded at $26.50 \mathrm{~m}$. Constantly low values are recorded from $30.30 \mathrm{~m}$ to $30.60 \mathrm{~m}$. From $30.70 \mathrm{~m}$ upwards the $\delta^{13} \mathrm{C}$ record shows a gradual increase to values of ca. $1.5 \%$.

The $\delta^{18} \mathrm{O}$ curve shows a trend similar to that of $\delta^{13} \mathrm{C}$ as shown in figure 3 .

\section{Calcareous plankton}

Calcareous nannofossil assemblages are common throughout the section even if not well diversified. Preservation is mostly poor, although moderate in some samples. Cretaceous reworked specimens are present in a few samples.

All the markers defining the standard calcareous nannofossil zones of Martini [1971] and Okada and Bukry [1980] across the P-E transition occur in the studied material. The distribution of the identified species is reported in table I. As far as the definition and the systematic position of the species of the Rhomboaster-Tribrachiatus lineage are concerned, we refer to Angori and Monechi [1995] and Monechi et al. [2000].

The main bioevents observed in the surveyed interval are reported in figure 4. Discoaster multiradiatus, the First Occurrence (FO) of which defines the NP8/NP9 zonal boundary of Martini [1971] and the CP7/CP8 zonal boundary of Okada and Bukry [1980] is present from the bottom of the studied interval. At $30.30 \mathrm{~m}$ the FO of Rhomboaster bramlettei is recorded. Rare specimens of Tribrachiatus digitalis occur at $33.90 \mathrm{~m}$, whereas the Last Occurrence (LO) of Rhomboaster contortus defines the NP10/NP11 and the $\mathrm{CP} 9 \mathrm{a} / \mathrm{b}$ zonal boundaries at $37.90 \mathrm{~m}$ where the FO of $T$. orthostylus is recorded.

The biostratigraphic analysis of planktonic foraminifera has allowed us to identify the LO of Globanomalina pseudomenardii at $27.90 \mathrm{~m}$ and the LO of Morozovella velascoensis at $31.50 \mathrm{~m}$ (fig. 4).

\section{Calcareous benthic foraminifera}

Calcareous benthic foraminifera are continuously present in the studied interval. Assemblages are moderately rich but poorly preserved. The clayey level at $30.30 \mathrm{~m}$ contains a depauperate fauna; only 8 , badly preserved, specimens were recovered from $250 \mathrm{~g}$ of dried sediment.

A typical bathyal Paleocene fauna is present up to $30.30 \mathrm{~m}$ where Gavelinella beccariiformis, Pullenia coryelli, Cibicides hyphalus, and Dorothia retusa last occur (fig. 4). Up to this level these taxa are quite common and cooccur with many typical Velasco elements. Some Midway taxa are also present.

From $30.60 \mathrm{~m}$ upwards the assemblages are dominated by large sized Cibicidoides indicating that a faunal turnover occurred between $30.30 \mathrm{~m}$ and $30.60 \mathrm{~m}$. Although the ana-

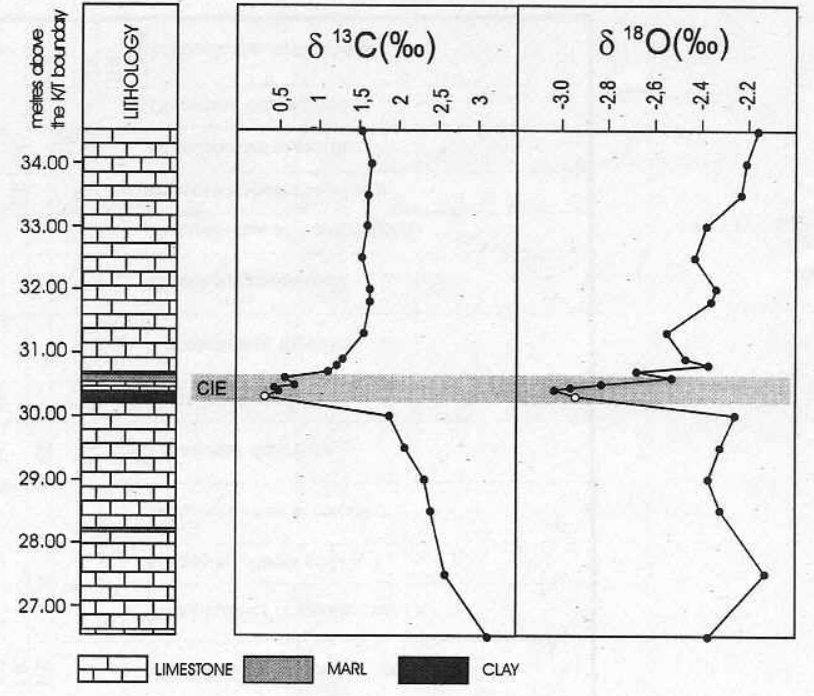

FIG. 3. - Oxygen and carbon isotope record across the P-E transition in the Contessa Road section. Isotopic result from $30.30 \mathrm{~m}$ (marked by a white circle) may represent diagenetic signature rather than original seawater values (see also text).

FIG. 3. - Enregistrement isotopique (oxygène et carbone) dans l'intervalle représentant la transition $P-E$ dans la coupe de la «Contessa Road». Le résultat isotopique de $30,30 \mathrm{~m}$ (marqué par un cercle blanc) peut représenter une signature diagénetique plutôt que des valeurs originales (voir également le texte)

lysis does not allow to quantify it, a drop in diversity has been observed where the minimum $\delta^{13} \mathrm{C}$ value is recorded.

\section{DWAF}

The quantitative analysis reveals the presence of rich and diversified agglutinated foraminiferal assemblages. Preservation is generally very good. Seventy-three species belonging to 35 genera have been identified (tab. II).

Assemblages are dominated by the epifaunal erect suspension feeder Rhizammina algaeformis throughout the studied interval. However, a bloom of tapered/flattened morphotypes, mainly due to increased abundances of the infaunal opportunistic Spiroplectammina spectabilis, occurs from $28.50 \mathrm{~m}$ to $29.80 \mathrm{~m}$ (fig. 5). This event is accompanied by the invasion and/or increase in abundance of taxa which are typically well distributed in shallower water settings, such as Arenobulimina, Clavulinoides, Dorothia, Remesella, and Tritaxia. In this stratigraphic interval the entrance of Karrerulina coniforms and $K$. horrida $(28.20 \mathrm{~m})$, the LO of Cribrostomoides trinitatensis and the FO of Reophax elongatus $(29.60 \mathrm{~m})$ are observed.

A very poor assemblage occurs in the clayey layer at $30.30 \mathrm{~m}$ where only 5 , badly preserved, specimens were recovered from $250 \mathrm{~g}$ of dried sample. A drop in diversity to the minimum value is recorded at $30.50 \mathrm{~m}$. Above this level diversity remains fairly low up to the top of the studied interval.

At $30.99 \mathrm{~m}$ a bloom of infaunal globular morphotypes (mainly due to increasing abundance of Repmanina charoides) is observed (fig. 5).

\section{DISCUSSION}

According to Corfield et al. [1991], the Paleocene to Eocene Scaglia limestones are strongly affected by diagenesis and, therefore, oxygen isotope values must be disregarded. A 


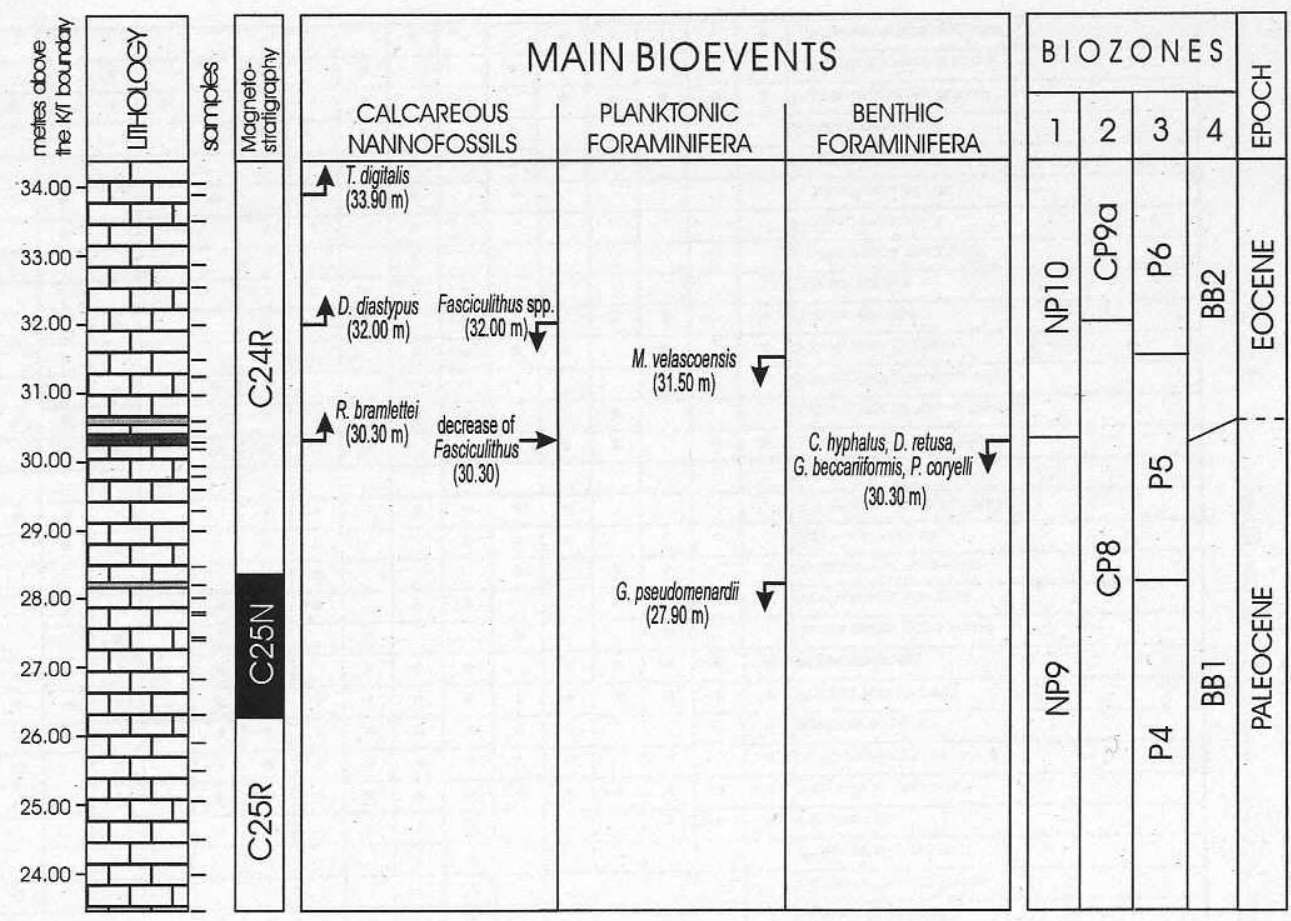

FIG. 4. - Bioevents recognised in the calcareous plankton and calcareous benthic foraminiferal distribution across the P-E transition in the Contessa Road section. Different biozonal schemes according to their authors are reported as : 1) Martini [1971]; 2) Okada and Bukry [1980]; 3) Berggren et al. [1995]; 4) Berggren and Miller [1989]. Magnetostratigraphy after Lowrie et al. [1982]. The duplicated interval, previously indicated in figure 2, is not reported.

FIG. 4. - Bioévénements indentifiés dans la distribution du plancton calcaire èt de foraminifères benthiques calcaires dans l'intervalle représentant la transition P-E dans la coupe de la «Contessa Road». Les échelles biostratigraphiques selon leurs auteurs sont le suivantes: 1) Martini [1971]; 2) Okada et Bukry [1980]; 3) Berggren et al. [1995]; 4) Berggren et Miller [1989]. Magnétostratigraphie d'après Lowrie et al. [1982]. L'intervalle dupliqué, indiqué précédemment dans la figure 2, n'est pas marqué.

$\delta^{13} \mathrm{C}$ record similar to that observed in this study has been reported by Corfield et al. [1991] from the P-E transition of the nearby Contessa Highway section. However, the lowest value recorded by those authors across the P-E transition is close to $1.5 \%$ and, therefore, much higher than

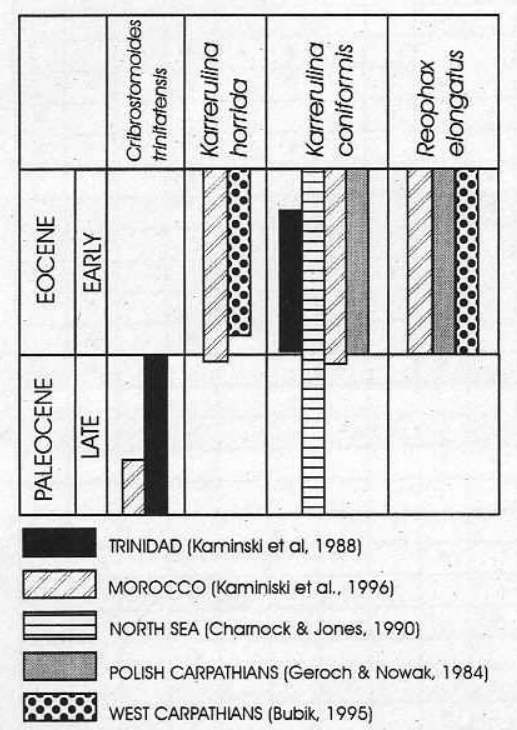

FIG. 5. - Comparison of the distribution of some DWAF taxa across the P-E transition from different locations.

FIG. 5. - Comparaison de la distribution des espèces de DWAF dans l'intervelle représentant la transition $P-E$ dans des localités différentes. the minimum recorded at the Contessa Road at $30.30 \mathrm{~m}$ $(0.31 \%$ ) . This discrepancy is only apparent because this interval in the Contessa Highway section, now covered, was not sampled being affected by tectonic disturbances [Corfield et al., 1991].

According to the litho- and magnetostratigraphic interpretation of Lowrie et al. [1982], the negative carbon isotope shift in the Contessa Road section would occur in the lower fourth of Chron C24r. The interval where the lowest values are recorded is, therefore, interpreted to be coeval to the well known Carbon Isotopic Excursion (CIE) occurring globally close to the end of the Paleocene.

Below the CIE a peculiar clay layer interrupts the limestone and marl sequence of the Paleocene to Eocene Scaglia Rossa Formation. This layer has a peculiar microfossil content. It is, in fact, very rich in calcareous nannofossils, but contains an impoverished planktonic foraminiferal assemblage and is virtually devoid of benthic foraminifera (13 specimens per $250 \mathrm{~g}$ of dried sediment including both calcareous forms and DWAF). This clay layer is reminiscent of the clay beds, also described as Carbonate Dissolution Interval (CDI), observed across the upper Paleocene to lower Eocene from the Zumaya [Schmitz et al., 1997], Caravaca [Canudo et al., 1995], Trabakua [Orue-Extebarria et al., 1996] and Alamedilla [Arenillas and Molina, 1996] sections in Spain. Similarly to the CDI of the Zumaya and Alamedilla sections, it contains enriched nannofossil assemblages, and depauperate foraminiferal assemblages. It generally, occurs just below the minimum values recorded in $\delta^{13} \mathrm{C}$ record. However, it seems likely that the $\delta^{13} \mathrm{C}$ value recorded from the clayey layer at $30.30 \mathrm{~m}$ might be a diagenetic artifact due to an enrichment in diagenetic calcite as documented in washed residues from this layer. On the other 


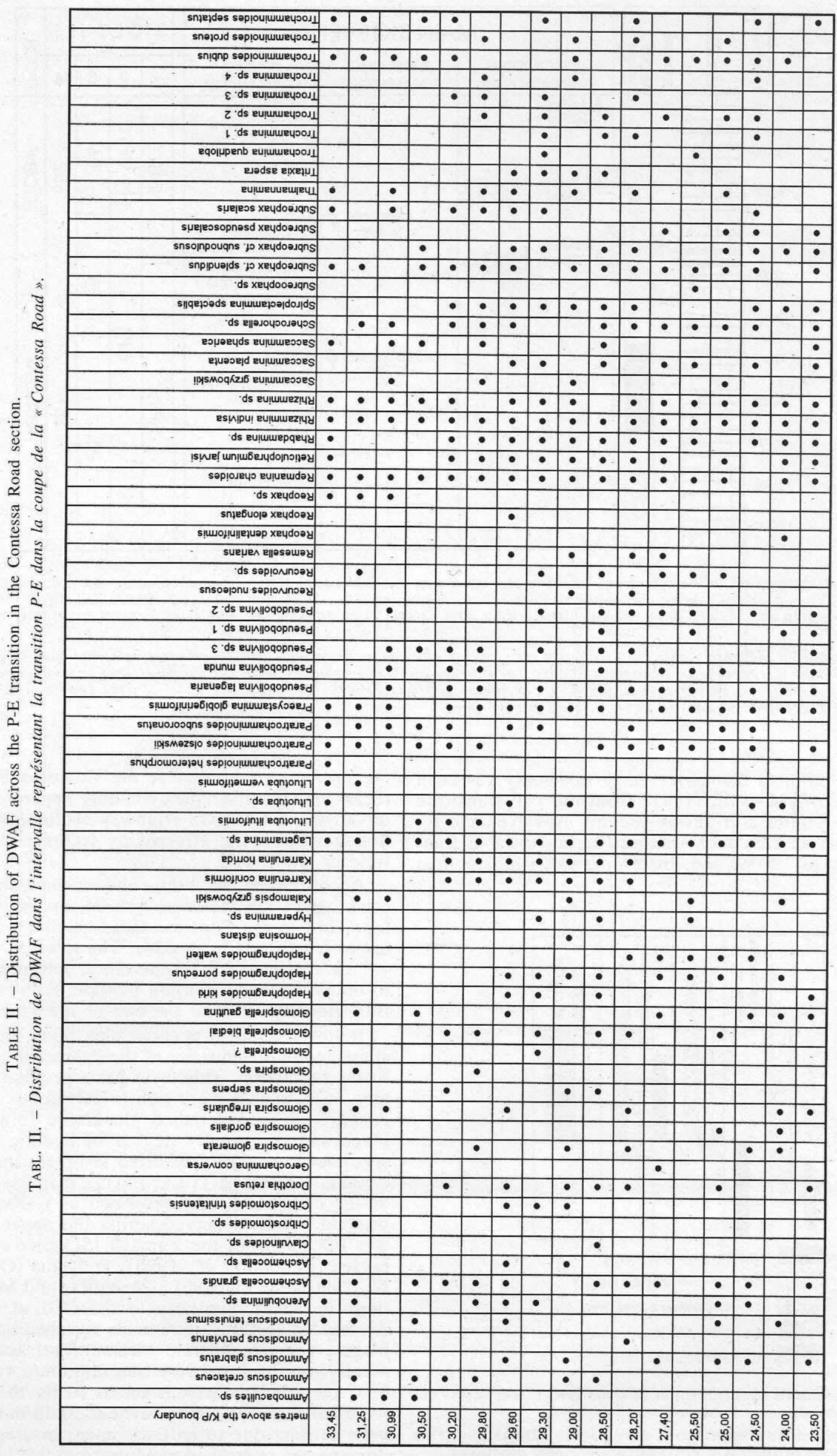






FIG. 6. - Bioevents recognised in the DWAF assemblages across the P-E transition in the Contessa Road section. The duplicated interval, previously indicated in figure 2, is not reported.

FIG. 6. - Bioévénements identifiées dans les associations DWAF dans l'intervalle représentant la transition P-E dans la coupe de la "Contessa Road". L'intervalle dupliqué, indiqué précédemment dans la figure 2, n'est pas marqué.

hand, diagenetic alteration of the isotopic signal across the $\mathrm{P} / \mathrm{E}$ boundary and particularly within the CDI is a common feature in several sections [see Schmitz et al., 1997].

Stratigraphic distribution of calcareous nannofossils is used to assign the lower part of the studied interval to the Discoaster multiradiatus Zone (NP9) of Martini [1971] and CP8 of Okada and Bukry [1980] based on the presence of D. multiradiatus in the lowest sample (fig. 4 , tab. I). The occurrence of cubic forms and successively of all the species of the Rhomboaster-Tribrachiatus lineage is used to characterise the P-E transition and to define the NP9/NP10 zonal boundary at $30.30 \mathrm{~m}$ by the FO of $R$. bramlettei. In the last few years several controversies have evolved regarding the definition and the systematic position of the marker species used to define the P/E boundary [Bybell and Self-Trail, 1995; Angori and Monechi, 1995; Wei and Zhong, 1996; Aubry, 1995, among others]. Consequently, different interpretations of the same data have developed and, accordingly, various events characterising the P-E transition can occur either in Zone NP9 or NP10. We follow Bybell and Self-Trail [1995] who, including R. cuspis of many authors in $R$. bramlette $i$, lowered the position of the NP9/NP10 zonal boundary. Our $R$. bramlettei var. $T$ can be considered conspecific of $T$. bramlettei of Aubry et al. [1996]. A decrease in abundance of Fasciculithus spp. is recorded at $30.30 \mathrm{~m}$ slightly below the CIE, while the LO of this genus occurs at $32.00 \mathrm{~m}$. At the same level the appearance of Discoaster diastypus marks the CP8/CP9 zonal boundary. Rare specimens of $T$. digitalis, species used by Aubry [1995] to subdivide the NP10 Zone, occur at $33.90 \mathrm{~m}$, whereas the LO of $R$. contortus defines the NP10/NP11 and the CP9a/b zonal boundaries at $37.90 \mathrm{~m}$.

The distribution of planktonic foraminifera fits the biostratigraphic interpretation based on calcareous nannofossil and magnetostratigraphic and carbon isotope records. The disappearance of Globanomalina pseudomenardii at 27.90 $\mathrm{m}$, where we place the P4/P5 zonal boundary (fig. 4), falls close to the boundary between Chrons C25n/C24r. The last occurrence of Morozovella velascoensis marks the P5/P6 zonal boundary of Berggren et al. [1995] at $31.50 \mathrm{~m}$ and falls, therefore, in the lower fifth of Chron C24R following the magnetostratigraphy given by Lowrie et al. [1982].

Calcareous benthic foraminiferal distribution allows us to place the BB1/BB2 zonal boundary of Berggren and Miller [1989] between $30.30 \mathrm{~m}$ and $30.60 \mathrm{~m}$. Gavelinella beccariiformis, Pullenia coryelli, Cibicides hyphalus, and Dorothia retusa which are generally documented from the pre-BEE Paleocene worldwide [Tjalsma and Lohmann, 1983; Berggren and Miller, 1989; Thomas, 1989, 1992; Orue-Extebarria et al., 1996; Speijer et al., 1995] are observed up to $30.30 \mathrm{~m}$ but are not present at $30.60 \mathrm{~m}$. Below this interval, these taxa are quite common therefore allowing to easily recognise a distinct $\mathrm{BEE}$ within planktonic foraminiferal Zone P5. Such event would occur at the boundary between calcareous nannofossil Zones NP9 and NP10, that is in the upper part of Zone CP8 and lower part of Chron C24r.

In the same interval, DWAF assemblages show a marked drop in diversity to the minimum value recorded in the studied interval (fig. 5). Prior to this event, a bloom of $S$. spectabilis and the invasion of shallower water taxa characterised the pre-BEE event recognised in calcareous foraminiferal assemblages. Such a change recorded in the DWAF assemblages might be indicative of a gradual initiation of the P-E transition benthic event which, based on a sedimentation rate of $7 \mathrm{~m} / \mathrm{m}$.y., would have started some 150 k.y. before the BEE.

The bloom of Repmanina charoides recorded just above the CIE also seems to be of use for stratigraphic correlation across the P-E transition in deep-water settings. It occurs, in fact, just above the BEE observed in the calcareous benthic foraminiferal assemblages and might be coeval to the entrance of the Glomospira-Ammodiscus assemblage described by Kaminski et al. [1996] from the Paleocene-Eocene Talaa Lakrah section in northern Morocco. Similar assemblages with common Glomospira and Ammodiscus have been described from the lower Eocene of the Alpine Carpathian region [Jurkiewicz, 1967; Morgiel and Szymakowska, 1978; Morgiel and Olszewska, 1981, 1982] and from the lower part of Zone NP10-NP12 (undifferentiated) in the Schlieren flysch of the Alpine Flysch Zone of Switzerland. Kaminski et al. [1990] reported the range of Glomospira as confined to the lower Eocene at Site 643 in the Norwegian Sea. A remarkable bloom of $R$. charoides occurs in the Trabakua Pass section in the Basque Basin where this taxon constitutes the $50 \%$ of the whole assemblage at the base of the benthic foraminiferal Zone BB2 [Coccioni et al., 1995; Orue-Extebarria et al., 1996]. Higher abundances of Glomospira representatives (including $R$. charoides) have been reported in calcareous nannofossil Zones NP9 and NP10, and planktonic foraminiferal Zone P5 by Bubik [1995] from the Bile Karpaty Unit (West Carpathian).

Across the BEE and CIE, a succession of discrete events within the DWAF assemblages is recorded. Karrerulina coniformis and $K$. horrida first occur at $28.20 \mathrm{~m}$, Reophax elongatus at $29.60 \mathrm{~m}$ where Cribrostomoides trinitatensis last occurs. As shown in figure 6 , these taxa display stratigraphically comparable FOs and LOs as observed in other sites and might be considered accessory bioevents for the Late Paleocene to Early Eocene transition besides the entrance of the Repmanina-Glomospira-Ammodiscus assemblage. 


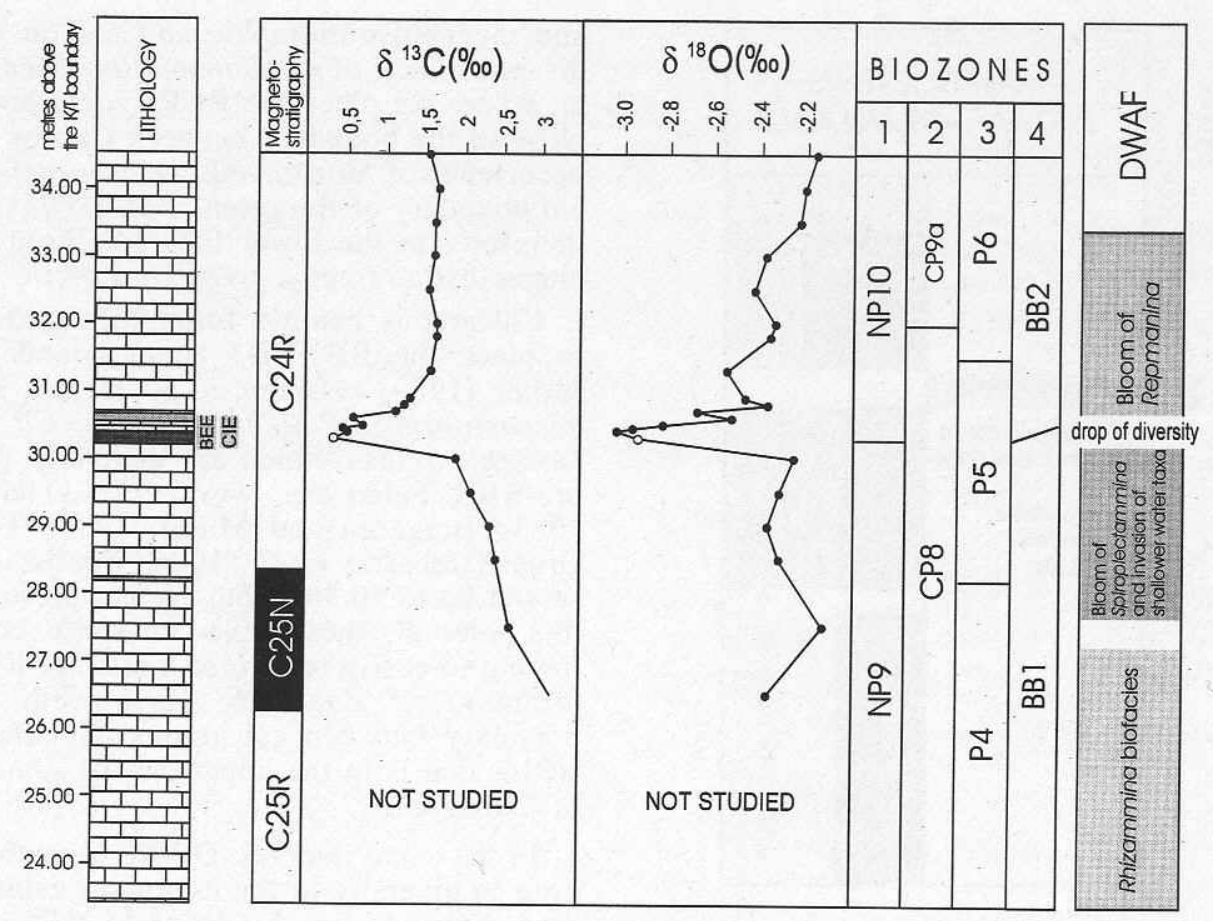

FIG. 7. - Summary scheme for magnetostratigraphy, stable isotopes, and biostratigraphy (calcareous nannofossils, planktonic foraminifera, deep water benthic foraminifera) and bioevents in the DWAF assemblages across the P-E transition in the Contessa Road section. The duplicated interval, previously indicated in figure 2 , is not reported.

FIG. 7. - Schéma recapitulatif de la magnétostratigraphie, des isotopes stables, de la biostratigraphie (nannofossiles calcaires, foraminifères planctoniques, foraminifères benthiques d'eau profonde), et des bioévénements dans le DWAF dans l'intervalle représentant la transition P-E dans la coupe de la "Contessa Road». L'intervalle dupliqué, indiqué précédemment dans la figure 2, n'est pas marqué.

\section{SUMMARY}

The Contessa Road section offers the rare opportunity to calibrate the geochemical, and bio- and magnetostratigraphic record across the P-E transition (fig. 7).

A negative shift of carbon isotope values corresponding to the well known CIE that occured globally at the end of the Paleocene Epoch is recorded in the lower part of Chron C24r, within planktonic foraminiferal Zone P5 and at the NP9/NP10 calcareous nannofossil zonal boundary, that is in the upper part of Zone CP8.

A distinct turnover in calcareous benthic foraminifera (BEE) has been identified within Zone P5 and at the calcareous nannofossil Zones NP9/NP10 zonal boundary, that is in the upper part of Zone CP8 and in the lower part of Chron $\mathrm{C} 24 \mathrm{r}$.

The comparison of DWAF and calcareous benthic foraminiferal records has allowed us to directly calibrate the faunal turnover recorded by these two groups across the P-E transition. A marked decrease in DWAF diversity occurs within the same stratigraphic interval where the BEE is recorded in the calcareous benthic foraminiferal assemblage. However, the record of DWAF indicates a gradual initiation of such a change beginning some $150 \mathrm{k} . \mathrm{y}$. before the BEE with the entrance of shallower water taxa.

A succession of events has been recognised in the DWAF assemblages across the P-E transition which might be of use for supra-regional stratigraphic correlation across the P-E transition in deep water settings.

Acknowledgements. - We thank W.A. Berggren, X. Orue Extebarria, and L. Stott for their helpful suggestions which greatly improved the manuscript. This work has been supported by CNR grant CT97.00285.CT05 Progetto "Stratigrafia Integrata"- Sottoprogetto Paleogene-Cretacico (Coord. I. Premoli Silva.) and by funds M.U.R.S.T. $60 \%$ to R.Coccioni.

\section{References}

ANGORI E. \& MONECHI S. (1995). - High resolution calcareous nannofossil biostratigraphy across the Paleocene/Eocene boundary at Caravaca (southern Spain). - Isr. J. Earth Sci., 44, 197-206.

Arenillas I. \& Molina E. (1996). - Bioestratigrafia y evolución de las asociaciones de foraminiferos planctónicos del transito Paleoceno-Eoceno en Alamedilla (Cordilleras Béticas). - Rev. Esp. Micropaleontol., 18, 76-96.
AUBRY M.P. (1995). - Towards an upper Paleocene-lower Eocene high resolution stratigraphy based on calcareous nannofossil stratigraphy. - Isr. J. Earth Sci., 44, 239-253.

Aubry M.P., Berggren W.A., Stott L. \& Sinha A. (1996). - The upper Paleocene-lower Eocene stratigraphic record and the Paleocene/Eocene boundary carbon isotope excursion : implications for geochronology. In: R. R.W.O'B. KNOX, R.M. CORFIELD, and R.E. DunAY Eds., Correlation of the early Paleogene in Northwest Europe. - Geol. Soc. Spec. Publ., 101, 353-380. 
Berggren W.A. \& Miller K.G. (1989). - Cenozoic bathyal and abyssal calcareous benthic foraminiferal zonation. - Micropaleontology, 35, 308-320.

Berggren W.A., Kent D.V., Swisher III C.C. \& Aubry M-.P. (1995). A revised Cenozoic geochronology and chronostratigraphy. SEPM, Spec. Publ., 54, 129-213.

BUBIK M. (1995). - Cretaceous to Paleogene agglutinated foraminifera of the Bílé Karpaty unit (West Carpathians, Czech Republic). In : M.A. Kaminski, S. Geroch and M.A. Gasinski (Eds.). Proceedings of the Fourth International Workshop on Agglutinated Foraminifera, Kraków, September 12-19, 1993. - Grzybowski Foundation Spec. Publ., 3, 71-116.

Bybell L.M. \& Self-Trail J. M. (1995). - Evolutionary, biostratigraphic, and taxonomic study of calcareous nannofossils from a continuous Paleocene-Eocene boundary section in New Jersey. - U.S. Geol., Surv., Prof. Pap., 1554, 36 pp.

Canudo J.I., Keller G. \& Ortiz N. (1995) - Planktic foraminiferal turnover and $\delta^{13} \mathrm{C}$ isotope record across the Paleocene-Eocene transition at Caravaca and Zumaya, Spain. - Palaeogeogr., Palaeoclimatol., Palaeoecol., 114, 75-100.

Channell J.E.T., Freeman R., Heller F. \& Lowrie W. (1982). - Timing of diagenetic haematite growth in red pelagic limestones from Gubbio (Italy). - Earth Planet. Sci. Lett., 58, 189-201.

CHARNOCK M.A. \& Jones R.W. (1990). - Agglutinated foraminifera from the Palaeogene of the North Sea. In : C. Hemleben, M.A. KAMINSKI, W. Kunnt \& D.B. ScotT Eds., Palaeoecology, biostratigraphy, palaeoceanography and taxonomy of agglutinated foraminifera. - NATO ASI Series $C$, Mathematical and Physical Sciences, Kluwer Academic Publisher, 327, 139-244.

Coccioni R., Di Leo R.C., Galeotti S. \& Monechi S. (1995). - Integrated biostratigraphy and benthic foraminiferal faunal turnover across the Paleocene-Eocene boundary at Trabakua Pass Section, northern Spain. - Palaeopelagos, 4, 87-100.

Corfield R.M., Cartlidge J.E., Premoli Silva I. \& Housley R.A. (1991). - Oxygen and carbon isotope stratigraphy of the Paleogene and Cretaceous limestones in the Bottaccione Gorge and the Contessa Highway sections, Umbria, Italy. - Terra Nova, 3, 414-432.

Cresta S., Monechi S. \& PARISI G. (1989). - Mesozoic-Cenozoic stratigraphy in the Umbria-Marche area. - Mem. Desc. Carta Geologica d'Italia, 39, 1-185.

GEROCH S. \& NowAK W. (1984). - Proposal of zonation for the late Tithonian-late Eocene, based upon arenaceous foraminifera from the Outer Carpathians, Poland. In : H.J. OeRTLI Ed., Benthos '83. 2nd International Symposium on Benthic Foraminifera (Pau, April 1983). - Elf Aquitaine, Esso REP an Total CFP, Pau and Bordeaux, 225-239.

JURKIEWICZ (1967). - Foraminifers in the sub-Menilitic Paleogene of the Polish Middle Carpathian. - Biuletyn Instytutu Geologicznego, 210, 5-116.

KAIHO K. (1994). - Planktonic and benthic foraminiferal extinction during the last 100 m.y. - Palaeogeogr., Palaeoclimatol., Palaeoecol., 111, 45-71.

Kaminski m.A., Gradstein F.M., Berggren W.A., Geroch S. \& Beckmann J.P. (1988). - Flysch type agglutinated foraminiferal assemblages from Trinidad : taxonomy, stratigraphy and paleobathymetry. - Abh. Geol., 41, 155-227.

Kaminski M.A., Gradstein F., Goll R.F. \& Gerig D. (1990). - Biostratigraphy and Paleoecology of deep-water agglutinated foraminifera at ODP Site 643, Norwegian-Greenland Sea. In : C. Hemleben, M.A. Kaminski, W. Kuhnt and D.B. Scott Eds. Palaeoecology, biostratigraphy, palaeoceanography and taxonomy of agglutinated foraminifera, 345-386. - NATO ASI Series $C$, Mathematical and Physical Sciences, 327, Kluwer Academic Publisher, Dordrecht.

Kaminski M.A., Kuhnt W. \& Radley J. (1996). - Palaeocene-Eocene deep water agglutinated foraminifera from the Numidian Flysch (Rif, northern Morocco): their significance for the palaeoceanography of the Gibraltar Gateway. - J. Micropal., 15, 1-19.

Kennett J.P. \& Stott L.D. (1991). - Terminal Paleocene deep-sea benthic crisis : sharp deep sea warming and paleoceanographic changes in Antarctica. - Nature, 353, 225-229.

Lowrie W., Alvarez A., Napoleone G., Perch-Nielsen K., Premoli Silva I. \& TOUMARKINE M. (1982). - Paleogene magnetic stratigraphy in the Umbrian pelagic carbonate rocks : The Contessa sections, Gubbio. - Geol. Soc. Amer. Bull., 93, 414-432..
Luterbacher H.P. (1964). - Studies in some Globorotalia from the Paleocene and lower Eocene of Central Apennines. - Eclogae Geol. Helv., 57, 631-730.

MCCREA J.M. (1950). - On the isotopic chemistry of carbonates and a paleotemperature scale. - J. Chem Phys., 18, 849-857.

MARTINI E. (1971). - Standard Tertiary and Quaternary calcareous nannoplankton zonation. In : A. FARINACCI Ed. Proc. 2nd Planktonic Conference. - Roma, Tecnoscienza, 739-785.

Monechi S., ANGori E. \& Von SAlis K. (2000). - Calcareous nannofossil turnover around the Paleocene/Eocene transition at Alamedilla (southern Spain). - Bull. Soc. géol. Fr., 171, 4 (in press).

Monechi S. \& Thierstein H. (1985). - Late Cretaceous-Eocene nannofossil and magnetostratigraphic correlations near Gubbio, Italy. - Mar. Micropaleontol., 9, 419-440.

Morgiel J. \& Olszewska B. (1981). - Biostratigraphy of the Polish External Carpathians based on agglutinated foraminifera. - Micropaleontology, 27, 1-30.

Morgiel J. \& OlSZEWSKA B. (1982). - Uniformity of the Tethyan faunas from Cretaceous and Palaeogene as shown by foraminifera from Morocco and Polish Flysch Carpathians. - Cah. Micropaléontol., 3, 45-33.

Morgiel J. \& Szymakowska F. (1978). - Stratygrafia Palaeocenu i Eocenu jednostki skolskiej. - Biuletin Instytutu Geologicznego, 310, 3971.

Napoleone G., Premoli Silva I., Heller F., Cheli P., Corezzi S \& FISCHER A.G. (1983). - Eocene magnetic stratigraphy at Gubbio, Italy, and its implications for Paleogene geochronology. - Geol. Soc. Amer. Bull., 94, 181-191.

OKADA H. \& BUKRY D. (1980). - Supplementary modification and introduction of code numbers to the low-latitude coccolith biostratigraphic zonation (Bukry, 1973; 1975). - Mar. Micropaleontol., 5, 321-325

Orue Extebarria X., Apellaniz E., Baceta J.J., Coccioni R., Di Leo R., Dinares-Turell J., Galeotti S., Monechi S., Nuñez-Betelu K., Pares J.M., Payros A., Pujalte V., Samso J.P., SerRA-Kiel J., Schmitz B. \& Tosquella J. (1996). - Physical and biostratigraphic analysis of two prospective Paleocene-Eocene boundary stratotypes in the intermediate-deep water Basque $\mathrm{Ba}$ sin, western Pyrenees: The Trabakua Pass and Ermua sections. - N. Jb. Geol. Paläont. Abh., 201, 179-242.

Robert C. \& KennetT J.P. (1994). - Antarctic subtropical humid episode at the Paleocene-Eocene boundary: clay mineral evidence. Geology, 22, 211-214.

Schmitz B., Asaro F., Molina E., Monechi S., von Salis K. \& Speijer R. (1997). - High-resolution iridium, $\delta^{13} \mathrm{C}, \delta^{18} \mathrm{O}$, foraminifera and nannofossil profiles across the latest Paleocene benthic extinction event at Zumaya, Spain. - Palaeogeogr., Palaeoclimatol., Palaeoecol., 133, 49-68.

Speijer R.P., Schmitz B., Aubry M.P. \& Charisi S.D. (1995). - The latest Paleocene benthic extinction event: Punctuated turnover in outer neritic foraminiferal faunas from Gebel Aweina, Egypt. In : M.P. AubrY and C. BENJAMINI Eds., Paleocene/Eocene boundary events in space and time. - Isr. J. Earth Sci., 44, 207-222.

Stott L.D, Sinha A., Thiry M., Aubry M.P. \& Berggren W.A. (1996) - The transfer of ${ }^{12} \mathrm{C}$ changes from the ocean to the terrestrial biosphere across the Paleocene/Eocene boundary : criteria for terrestrial-marine correlations. - Spec. Publ. Geol. Soc. London, 101, 381-400.

Thomas E. (1989). - Development of Cenozoic deep-sea benthic foraminiferal faunas in Atlantic waters. In : J.A. CRAME Ed., Origins and evolution of the Antarctic biota. - Spec. Publ. Geol. Soc. London, 47, 283-296.

Thomas E. (1992). - Cenozoic deep-sea circulation : evidence from deepsea benthic foraminifera. In : J.P. KENNETT and D. WRANKE Eds., The Antarctic paleoenvironment: A perspective on global change. - AGU Antarct. Res. Ser., 56, 141-165.

Thomas E. \& Shackleton N.J. (1996). - The latest Paleocene benthic foraminiferal extinction and stable isotope anomalies. - Spec. Publ. Geol. Soc, London, 101, 401-441.

Tualsma R.C. \& Lohmann G.P. (1983). - Paleocene-Eocene bathyal and abyssal benthic Foraminifera from the Atlantic Ocean. - Micropaleontology Spec. Publ., 4, 1-90.

WEI W. and ZHONG S. (1996). - Taxonomy and magnetochronology of Tribrachiatus and Rhomboaster, two genera of calcareous nannofossils. - J. Paleont., 70 (1), 7-22. 